\title{
DISCURS I ESTRATĖGIES DEL PODER REIAL A CATALUNYA AL SEGLE XIV ${ }^{1}$
}

\author{
Flocel SABATÉ \\ Universitat de Lleida
}

\begin{abstract}
SUMARI
1. El discurs del poder sobirà: el rei d’Aragó com a príncep de Catalunya.- 2. Les maniobres per a la concreció $i$ afermament del poder reial.- 3. Dificultats i topalls en la pretensió reial: l'estat real del poder.4. La força municipal i el poder reial.- 5. L'equilibri final.- 6. El discurs del poder reial en l'elaboració de la història de Catalunya.
\end{abstract}

1. EL DISCURS DEL PODER SOBIRÀ:

El REI D'ARAGó COM A PRÍNCEP DE CATALUNYA

L'estesa del Dret Comú, de la mà dels juristes que assoleixen una plena presència en tot l'espectre social baix-medieval, infon en el rei els raonaments que el transformen, de monarca regent de la societat, en príncep sobirà del país. La dispersió que, en diferent manera, derivà de l'esclat feudal, ara es corregeix amb el vèrtex reial presidint la piràmide de fidelitats: és l'argumentació que cohesiona el regne francès superant la

\footnotetext{
'Com en altres ocasions similars, la brevetat exigida imposa no sols condensar la informació sinó també sacrificar l'aparell crític, que només s'esmentarà en citacions concretes. En aquests casos les abreviatures emprades són: ACA, Arxiu de la Corona d'Aragó; ADPO, Archives Départementales des Pyrenées-Orientales; AHCG, Arxiu Històric de la Ciutat de Girona; AHCO, Arxiu Històric Comarcal d'Olot; AHCT, Arxiu Històric Comarcal de Tàrrega; AHCTE, Arxiu Històric Comarcal de les Terres de l'Ebre; AHMV, Arxiu Històric Municipal de Vic; AHS, Arxiu Històric de Sabadell.
} 
pluralitat de senyorius perquè rex Franciae est princeps in regno suo ${ }^{2}$; que atorga les armes jurídiques ${ }^{3}$ per enaltir la monarquia castellana ${ }^{4}$ que alhora conviu ${ }^{5}$ amb la imperant senyorialització de rendes i jurisdicció ${ }^{6}$; que empeny el monarca navarrès damunt de la diversitat social i jurídica ${ }^{7}$; o que consolida un rei anglès que va essent apreciat, més que com a Rex Anglorum, com a Rex Angliae ${ }^{8}$. La visió global és una suma de territoris nítidament definits i diferenciats, cadascun amb uns súbdits regits pel respectiu monarca, el qual els corona en sobirana equivalència amb els homòlegs dels altres països, tal i com implícitament ho proclama el papa Climent V el $1313^{9}$.

El plantejament comporta tant l'assumpció de la singularització territorial com l'acceptació d'una monarquia que inclou entre els seus trets distintius la possessió de tota la capacitat jurisdiccional des d'uns orígens remots, per bé que tal vegada havent de remuntar els efectes d'excessives

\footnotetext{
${ }^{2}$ Walter UlLmann, The Development of the Medieval Idea of Sovereignty, "English Historical Review", LXIV (1949), p. 10.

${ }^{3}$ Aquilino Iglesia FerReIros, La creació del Dret. Una història de la formació d'un dret estatal espanyol, vol. II, Editorial Gráficas Signo, Barcelona, 1993, pp. 22-46; José Maria Monsalvo ANTON, Poder político y aparatos de estado en la Castilla bajomedieval. Consideraciones sobre su problemática, "Studia Historica. Historia Medieval", IV-2 (1986), pp. 116-117.

${ }^{4}$ José María Monsalvo Antón, Historia de los poderes medievales, del Derecho a la Antropología (el ejemplo castellano: monarquía, concejos y señoríos en los siglos XII-XV), "Historia a Debate. Medieval", Carlos Barros, ed., Santiago de Compostela, 1995, pp. 114-117; Paulino IRADIEL, Formas del poder y de organización de la sociedad en las ciudades castellanas de la baja Edad Media, "2as. Jornadas de Estudios Históricos. Estructuras y formas del poder en la historia", Universidad de Salamanca, Salamanca, 1990, pp. 44-49; Alan DEYERMOND, La ideología del Estado moderno en la literatura española del siglo XV. Adeline Rucquoi, ed., "Realidad e imagenes del poder. España a fines de la Edad Media", Ambito, Valladolid, 1988, p. 175; José Manuel NIETO SORIA, Fundamentos ideológicos del poder en Castilla (siglos XIIIXVI), Eudema, Madrid, 1988, p. 132.

5Julio VALDEÓn, La victoria de Enrique II: Los Trastàmaras en el poder, "Génesis Medieval del Estado Moderno: Castilla y Navarra (1250-1370)", Adeline Rucquoi, coord., Ambito, Valladolid, 1987, pp. 245-258.

${ }^{6}$ Ignacio AlvaREZ BORGE, Monarquía feudal y organización territorial. Alfoces y merindades en Castilla (siglos X-XIV), CSIC, Madrid, 1993, pp. 185-197.

${ }^{7}$ José Maria LACARRA, Sobre la recepción del derecho romano en Navarra, "Anuario de Historia del Derecho Español" XI (1934), pp. 457-467.

${ }^{8}$ Walter Ullmann, Personality and Territoriality in the "Defensor Pacis": The Problem of Political Humanism, "Medioevo. Rivista di Storia della filosofia medievale", VI (1980), p. 403.

${ }^{9}$ Matisant-ho, però, a tenor d'una adient contextualització: Mario delle PIANE, Intorno ad una bolla papale, la "Pastoralis cura" di Clemente V, "Rivista di storia del diritto italiano", XXXI (1958), pp. 23-56.
} 
lliberalitats anteriors o d'abusos comesos per alguns súbdits entorn de la fragmentació feudal ${ }^{10}$. L'ús d'aquest mateix discurs a Catalunya obre un problema immediat: el monarca català no pot, pròpiament, basar el seu poder en la invocació del domini superior passat, perquè el país català no parteix de la disgregació d'una unitat alt-medieval sinó el contrari, d'una convergència de vectors sòcio-econòmics, polítics, culturals i lingüístics gresolats entre els segles VIII i XII". La preeminència del comte de Barcelona, culminant la via de cohesió d'aquest garbuix en la dotzena centúria, ja havia obert la problemàtica entorn de la titulació superior, forçant a una extrapolació de la noció de comtat de Barcelona, que deixa de tenir un sentit físic per aglutinar els diversos dominis catalans del seu titular, com es consolida en les centúries posteriors ${ }^{12}$.

El segle XIII persevera en aquest afermament, amb moments prou significatius com la intervenció en el comtat d'Urgell ${ }^{13}$, la cessió de qualsevol dret de la corona francesa sobre el dominis regentats per Jaume I Corbeil, $1258^{14}$ - i la infeudació del Pallars Sobirà el $1295^{15}$. Ja al llarg de tota la centúria, el titular barceloní no dubta de la seva superioritat sobre el conjunt català ${ }^{16}$, un país amb denominació travada des del segle anterior i prou cohesionat com perquè ell pugui convocar els diferents estaments en unes corts particulars fornidores d'una legislació superior pròpia o perquè, en les darreres dècades, delimiti amb l'esment territorial global l'espai

${ }^{10}$ Es la reconstruction du pouvoir royal (Jean IMBERT, Gérard SAUTEL et Marguerite Boulet-SAuTEL, Histoire des Institutions et des faits sociaux (Xe-XIXe siècle), Presses Universitaires de France, Paris, 1956, pp. 73-122).

"Michel Zimmermann, De pays catalans à la Catalogne: gènese d'une représentation, "Histoire et Archeologie des terres catalanes au Moyen Age", Philippe SENNAC, ed., Presses Universitaires de Perpignan, Perpinyà, 1995, pp. 71-85.

${ }^{12}$ Flocel SABATÉ, El territori de la Catalunya inedieval, Fundació Salvador Vives Casajuana, Barcelona, 1996 (en premsa).

${ }^{13}$ Flocel SABATÉ, Organització administrativa i territorial del comtat d'Urgell, "El comtat d'Urgell", Universitat de Lleida-Institut d'Estudis Ilerdencs, Lleida, 1995, pàgs. 38-39.

${ }^{14} \mathrm{~S}$ 'hi inclouen els comtats considerats catalans exceptuant el Pallars i la Ribagorça $(\mathrm{Cl}$. Devic-J. VaisSETTE, Histoire Génerale du Languedoc, VI, ed. Privat, Toulouse, 1879, p. 859).

${ }^{15}$ Josep BAUCELLS I REIG, La successió dels comtes de Pallars en el dos-cents, "X Congreso de Historia de la Corona de Aragón (Zaragoza, 1979)", Institución Fernando el Católico, Comunicaciones 3, 4 y 5, Zaragoza, 1980, p. 36.

${ }^{16}$ Crònica o llibre dels Feits, cap. 392 ("Les quatre grans cròniques", Ferran Soldevila, ed., Editorial Selecta, Barcelona, 1983, pàg. 145). 
d'actuació i definició dels seus representants: baiulo Cathalonie ${ }^{17}$ es diu l'oficial creat per Pere el Gran ${ }^{18}$. Aquest afany, però, col.lideix tant amb uns emergents municipis com amb uns envigorits barons. Sota una monarquia amb el patrimoni erosionat en temps de Pere el Catòlic i una capacitat ressentida durant la sobtada minoritat dels primers anys de Jaume I, els poders locals avancen en l'afermament de l'autonomia governativa $i$ normativa, en l'accentuació de l'empenta expansiva i en la projecció sobre la regió d'influència, procurant, a fi d'assegurar aquesta dinàmica, tant mediatitzar l'oficial jurisdiccional i districtual reial com assolir el favor d'un monarca atorgador de garanties personals i exactives. En el mateix context, la noblesa pretén afermar les pròpies bases -superant les alteracions sòcioeconòmiques que, en canvi, enfonsaran famílies de la petita noblesa- i, sobretot, garantir una plena capacitat jurisdiccional, no esquivant l'enfrontament obert contra el propi monarca, amb els deseiximents de $1259^{19}$ i 1274 i topades com les de 1276, culminant amb l'assalt a Balaguer el $1280^{20}$.

En aquests moments, però, el gran argument pràctic en les pretensions del sobirà rau en la seva titulació com a rei. L'adopció del títol reial aragonès per tots els titulars del comtat de Barcelona des de 1162 afegeix una arma cabdal en la consolidació d'aquests sobre el conjunt de Catalunya. El comte de Barcelona passa a ser immediatament el rei per a tothom, i així és vist i tractat al marge de la procedència comtal dels dominis. Des del mateix segle XII popularment hom el veu com a rei clamamus regem li diuen, a Alfons el Cast, des de Font-rubí ${ }^{21}$ - i durant tota la baixa edat mitjana ell és lo senyor rei, tant pel poble que l'aclama en rebre'l o el plora en morir, com pels nobles que l'acaten, alhora que la invocació del casal d'Aragó és el crit de guerra de tots els qui combaten sota el seu estol defensant els dominis catalans.

\footnotetext{
${ }^{17}$ David Romano, Los funcionarios judios de Pedro el Grande de Aragón, "Boletín de la Real Academia de Buenas Letras de Barcelona", XXXIII (1969-1970), p. 15.

${ }^{18}$ Tomàs de Montagut I Estragués, El baile General de Cataluña (notas para su estudio), "Hacienda Pública Española", 87 (1984), pàg. 74.

${ }^{19}$ Francesc CARRERAS CANDI, Rebelió de noblesa catalana contra Jaume I en 1259, "Miscelànea Històrica Catalana", sèrie II, Imprenta de la Casa Provincial de Caridad, Barcelona, 1906, pp. 456-518.

${ }^{20}$ Francesc CaRRERAS CANDI, Lo siti de Balaguer del 1280, "Boletín de la Real Academia de Buenas Letras de Barcelona", III (1905-1906), pp. 70-79; "Miscelànea Històrica Catalana", sèrie II, Imprenta de la Casa Privincial de Caridad, Barcelona, 1906, pp. 49-56.
}

${ }^{21} \mathrm{ACA}$, pergamins, Extra-inventari, carpeta 360 , doc. 3288. 
Coherentment, els sobirans de Catalunya actuen com a reis i, al marge de la titulació comtal que en justifica el domini en aquestes contra$\operatorname{des}^{22}$, concedeixen titulacions nobiliàries de categoria formal idèntica $\mathrm{o}$ superior, amb les ereccions dels comtats de Prades (1324), de Cervera (1353), d'Osona (1356) i de Besalú (1368), el marquesat de Tortosa (1329) i els ducats de Girona (1351) i de Montblanc (1387). Les noves creacions nobiliàries es justifiquen com a gracioses concessions del sobirà, adreçades a bastir patrimonis per als membres de la família reial o a gratificar la magnam et integram affectionem del receptor, emetent, alhora, un reconeixement de la seva significació en la societat, tal com raona Pere III en elevar, el 1375 , el vescomtat de Cardona a comtat ${ }^{23}$.

Tot allò que est situs in Cathalonia escau a la reial sobirania, sense que hi valgui al.legar origens comtals aliens a la nissaga barcelonina, tal com el 1302 Jaume II explica al comte de Foix en recordar-li que, com a possessor del vescomtat de Castellbò, té el deure d'acudir cada vegada que

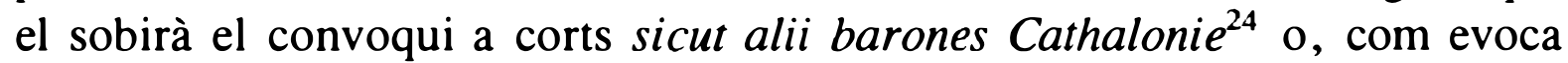
Pere III el 1345, en exigir, en una contrada plenament baronial com Andorra, aquell "iure generalis iurediccionis quam in dicta valle et omnibus partibus Cathalonie habere" 25 .

La compatibilització popular d'un ús restringit del locatiu regne d'Aragó centrat en l'espai aragonès i un altre extens identificat amb els dominis del sobirà, incloses les terres catalanes, respon a la cohesió assolida entorn del rei d'Aragó, argumentació que també divulga, encara més, el concepte de Corona d'Aragó, o simplement de Corona, en concordança amb

\footnotetext{
${ }^{22}$ Des de 1283 el monarca és obligat, constitucionalment, a titular-se comitem Barchinone (Cortes de Cataluña, "Cortes de los antiguos reinos de Aragón y de Valencia y Principado de Cataluña", I, Real Academia de la Historia, Barcelona, 1896, p. 149; Constitucions y altres Drets de Cathalunya, vol. I, Ilibre 1, títol XII.1 (Departament de Justícia de la Generalitat de Catalunya, Barcelona, 1995, p. 36).

${ }^{23}$ Joan Serra Vilaró, Història de Cardona, I, Imprenta Sugrañes, Tarragona, 1966, p. 309.

${ }^{24}$ Charles BAUdON DE MONY, Relations politiques des Comtes de Foix avec la Catalogne, jusqu'au commencement du XIVè siècle, II, ed. Alphonse Picard et Fils, libraires-éditeurs, Paris, 1896, p. 281.

${ }^{25} \mathrm{ACA}$, Cancelleria, reg. 1060, fol. 99 r.
} 
la general acceptació, en l'Europa baixmedieval ${ }^{20}$ d'aquest simbolisme al.legòric ${ }^{27}$.

De tota manera, la plena identitat pròpia de Catalunya, evident a tots el nivells, des del tractament institucional a la percepció comuna atenta a la nació catalana, incita a cercar un emmarcament específic per al domini del monarca sobre aquest espai, el qual s'encerta, amb la divulgació de la terminologia romanista, en la seva mateixa condició de príncep. Ell és, ben popularment, el princep e senyor ${ }^{28} \mathrm{~d}$ 'aquestes terres. I aquestes, amb plena acceptació des de mitjan segle XIV, configuren el Principat de Catalunya, denominació que assolirà un arrelament que permetrà, sobretot en la centúria següent, identificar el territori fins i tot al marge de la sobirania del rei d'Aragó i comte de Barcelona ${ }^{29}$.

Instal.lat en la preeminència pròpia del príncep e senyor, el sobirà serà interpel.lat pels súbdits que sol.licitaran gràcies et libertats (...) justicia et egualtats i defendre lurs lochs et heretats, com explica Pere III el $1383^{30}$.

\section{LES MANIOBRES PER A LA CONCRECIÓ I AFERMAMENT DEL PODER REIAL}

La posició del sobirà, més enllà del discurs justificatiu, requereix unes bases sostenidores fermes, i aquestes es resumeixen en dos pilars: rendes i jurisdicció. En l'ànim dels monarques tretzentistes hi batega, a través de diferents situacions i capacitats, l'interès per a vetllar ambdós eixos, dels quals depèn la veritable plasmació del poder reial.

Enfortir aquest i superar la delicada situació financera i jurisdiccional amb què trobà el tron és, clarament, l'objectiu de Jaume II mitjançant un

\footnotetext{
${ }^{26}$ Bernard GuenÉE, Occidente durante los siglos XIV y XV, Editorial Labor, Barcelona, 1973, pp. 93-94.

${ }^{27}$ Antony BLACK, El pensamiento político en Europa, 1250-1450, Cambridge University Press, Cambridge, 1996, pp. 294-295.

${ }^{28}$ AHCTE, Provisions, llibre 8, fol. 43 v; llibre 10, fol. 2 v; llibre 12, fol. 5 r, entre molts altres exemples.

${ }^{29}$ Flocel SABATÉ, El territori de la Catalunya medieval, Fundació Salvador Vives Casajuana, Barcelona, 1996 (en premsa).

${ }^{30}$ Josep Maria SaNS I TRA vé (Coord), Cort General de Montsó 1382-1384, Departament de Justícia de la Generalitat de Catalunya, Barcelona, 1992, p. 78.
} 
seguit d'actuacions ${ }^{31}$, àmplies $\mathrm{i}$ coherents, que marquen el regnat (12911327), especialment en les seves tres primeres dècades:

a) Augmentar els dominis territorials de la corona, mitjançant acords com els assolits sobre la baronia osonenca de Montcada el 1311 -amb Tona, Malla, Voltregà, Besora, Torelló i Curull, a més de Gurb-, sobre la baronia d'Entença (1313, aplicat el 1321) o respecte de Granollers (1316); adquisicions de llocs com Tous i l'Espelt (1318); i, sobretot, bescanvis, que aporten la important ciutat de Tortosa (1294) i els dominis de Sibil.la de Pallars al Berguedà -Berga, Montclar, Casserres, Merola, Puigarbessós, Fraumir, Bonner, Blancafort, Peguera, Montmajor, Querol i Tersà- (1309), a més de la Vall de Meià (1312), la part inferior de Vic (1315) i llocs menors com Josa (1318).

b) Mediatitzar grans espais baronials mitjançant la introducció del llinatge reial -comtats d'Urgell (1314) i d'Empúries (1325)- o intervenint en la seva gestió -vescomtat de Bas (1300)-, a més d'aconseguir l'acatament formal del comtat de Pallars Sobirà (1295), forçar reconeixements de superioritat sobre espais concrets al vescomte de Cabrera (1306-1311) i reblar el respecte del vescomte de Cardona (1319).

c) Escatir i discutir, puntualment i sobretot en les dues dècades inicials del segle XIV, la capacitat jurisdiccional sobre nombrosos indrets (Conill de Segarra, Montagut, Ripoll, Verges, Peratallada, Sant Adrià de Besòs...). La difusió de la disquisició romanista entre mer i mixt imperi ${ }^{32}$ facilita l'argumentació reial en molts casos on el feudatari al.lega una plena capacitat i el monarca una partió (Anglesola, Jorba, Campdevànol, Castellvell...) i permet estandaritzar el compartiment de poder en molts indrets (baronia de la Portella, Scala Dei, la Ràpita...).

d) Definir els dominis territorials i rendístics discutits amb poders baronials, com són els límits amb el comtat d'Urgell (1307-1309), la jurisdicció en els indrets meridionals del comtat d'Empúries (1304-1314) o les rendes en l'àmbit episcopal urgellenc (1305).

\footnotetext{
${ }^{31}$ L'actuació del mateix monarca a Aragó ha estat objecte de tractament a: Luis GoNZÁLEZ ANTón, Jaime II y la afirmación del poder monárquico en Aragón, "Aragón en la Edad Media" X-XI (1993), pp. 385-405.

${ }^{32}$ La fórmula, empentada des de la tretzena centúria, sembla que fins i tot fou exportada a altres contrades: Hilda GrassoTTI, Hacia las concesiones de señoría "con mero y mixto imperio", "Estudios en homenaje a Don Claudio Sánchez Albornoz en sus 90 años", III, Instituto de Historia de España, Buenos Aires, 1985, pp. 141-150.
} 
e) Vetllar per l'estat de les rendes disperses arreu del territori, sobretot les derivades de les castlanies. En el context ordenador de l'emfiteusi, malfiant dels detentors dels drets reials i reprenent una atenció a les situacions locals difícil d'efectuar en la convulsa centúria precedent, es pretén endreçar les percepcions concretes corresponents a la corona i vetllar per l'aplicació del lluïsme i el control dels deures dels castlans. A més d'empentar la capbrevació, de manera gairebé sistemàtica i progressivament exhaustiva, dels drets i rendes reials als diferents indrets del país, d'atendre les queixes populars contra exigències castlanes (Montanyana, Montmaneu, Terrassa, Oló, Olèrdola...) i de cercar una relació fiscal estable amb les poblacions reials a partir de la quèstia i la cena, s'imposen intervencions clarificadores als oficials ordinaris i s'endeguen comissions especials per investigar en indrets concrets (Peralada, Montpalau, Púbol...) o sobre conjunts espacials -marca la pauta la indagació al Bages el 1303-, reiterades sobretot en els territoris de nova incorporació als dominis reials -Berguedà (1310), Bas (1312), Osona 1315)-.

f) Imposar un marc competencial exclusiu del monarca arreu del país i en tots els espais jurisdiccionals, centrat en la concessió de fires i mercats (relativament acceptat en àmbits eclesiàstics i causa de forts enfrontaments amb nobles com el vescomte de Cardona), l'autorització de la construcció de fortaleses (motiu de topades amb els Cervià, el vescomte de Cabrera...), el control de camins i aigües (de reiterada exigència però amb aplicació impossible pel bloqueig dels poders baronials) i la persecució de la falsificació de moneda (única pretensió comunament acceptada sense oposició). El monarca aconsegueix incloure en el mateix conjunt la població jueva, precisament estesa arreu de Catalunya al llarg del segle XIII, bé que el reconeixement superior reial, avalat en el dret romà, no comportarà una ingerència en el regiment de les aljames situades en àmbit baronial, on prosseguirà el corresponent control nobiliari, interpretat ara com a concessió del sobirà, qui ha atorgar la licència de aljama. En aquest context, ultra invocar els Usatges de Barcelona, el monarca insisteix en valorar les Constitucions de Pau i Treva com a marc de competències d'exclusiva incumbència reial, la garantia i aplicació de les quals el faculta per a intervenir dins de tot el territori català, per la qual cosa als nobles que s'hi oposen, com el comte d'Empúries i vescomte de Bas el 1316, al.legant 
gaudir ells mateixos dins dels propis dominis de la pau i treva, contesta "quod nos et non alius in Cathalonia habemus pacem et tregua"33.

g) Visualitzar institucionalment la capacitat superior del monarca sobre tot el territori català, inclosos els espais baronials. Amb aquesta intenció el 1301 les vegueries reials s'estenen com una xarxa completa per damunt de la diversitat de jurisdiccions i concordant amb el discurs que vol imposar omnibus hominibus totius Regni sunt terre Domini ${ }^{34}$.

h) Millorar i clarificar la delegació territorial de la jurisdicció reial. Es negocia cas a cas l'absorció de l'ofici de cort $\mathrm{i}$ el traspàs de les seves funcions als batlles (Tàrrega, Montblanc, Manresa, l'Arboç, com havia succeït abans a Cervera) o als veguers (Lleida i abans Vilafranca del Penedès), abordant també casos més complexos com el de Prats de Segarra; es delimita el marc general entre el veguer com oficial de plena capacitat jurisdiccional i el batlle com oficial rendístic, acceptant en aquest l'actuació in civilibus o fins $\mathrm{i}$ tot les capacitats jurisdiccionals superiors on ja les gaudeix (Figueres, Torroella de Montgrí, Gurb, a més de Caldes de Malavella), optant per afegir-les en els nuclis emergents oposats a les respectives seus vicarials (Vilagrassa, Valls, Cambrils, Sarral, l'Arboç, Palamós, Muntanyana, Santpedor) i en capitals de vegueria com Manresa, Cervera, Camprodon, Tàrrega, Vilafranca del Penedès i Caldes de Montbui, a més dels casos de Granollers i Terrassa; es limiten les capacitats del veguer en sots-vegueries en benefici del sots-veguer, sobretot quan han sorgit tensions entre els governs locals de les capitals vicarial i sots-vicarial (Prats de Segarra, Copons, Piera, Pujalt i Sarral, a més d'Igualada i Moià). Alhora, intervencions puntuals sobre oficials sospitosos i la imposició tant del control ordinari del mestre racional com de mesures amb rang de constitució de cort -amb veguers sotmesos a triennalitat, judici de taula $\mathrm{i}$ l'obligació de no pertànyer als bàndols de l'indret ni tenir antecedents penals-pretenen afermar la qualitat i la imparcialitat en l'actuació districtual de delegació reial.

i) Millorar i agilitzar l'administració central. Es reprenen i s'articulen els oficis creats per Pere el Gran adreçats al control de les rendes i la despesa: mestre racional, batlle general i tresorer. S'ordena i impulsa la cancelleria, estabilitzant l'organigrama i volum del seu personal i diversifi-

\footnotetext{
${ }^{33}$ ACA, Cancelleria, reg. 243, fol. 93 r.

${ }^{34} \mathrm{ACA}$, Monacals-Hisenda, reg. 892, fol. $41 \mathrm{r}$.
} 
cant $\mathrm{i}$ ampliant les sèries de registres, introduint noves formes documentals i millores en el control de la registraciós ${ }^{35}$. L'intent de perfeccionar l'ensamblatge amb l'administració territorial mitjançant la figura intermèdia dels supraveguers és efímer (1303) en constatar que injecta major complexitat a l'administració, abocant, per tant, al tractament conjunt en la figura del vice-gerent del procurador general.

j) Foment i endreça dels arxius com a base per a fonamentar les disputes jurisdiccionals $\mathrm{i}$ de rendes. El monarca ${ }^{36}$ ordena a les corts territorials -batliars i sobretot vicarials- arranjar i trobar en l'arxiu els precedents d'actuació que convenen per a sostenir les posicions discutides. En la pròpia cort reial és ara quan es disposa adientment la documentació i s'articula, el 1318, l'espai físic de l'arxiu reial ${ }^{37}$. L'estructuració d'aquest comporta la redacció de memorials, que esdevenen la base de les indagacions en el foment de la renda i jurisdicció reial, tal i com s'aplica tant des de la mateixa cancelleria com des de la batllia general.

Aquest conjunt de línies són recollides i prosseguides pel successor de Jaume II. Alfons el Benigne (1327-1336) continua algunes de les iniciatives anteriors, com la cura, endreça $i$ ús de l'arxiu reial ${ }^{38}$, amb l'elaboració de nous memorials imbricats en les tasques portades a terme, precisament, per comissions específiques per al control de les rendes. Aquestes, que ara gaudeixen de major capacitat d'intervenció, analitzen sobretot les castlanies, amb els béns de tractament emfitèutic que en formen part, atenent la gestió i transmissió que se n'ha fet, perseguint els lluïsmes no percebuts i intentant corregir la dispersió i el diluïment de la renda

\footnotetext{
${ }^{35}$ José TrenChS-Antoni Maria ARAGó, Las cancillerías de la Corona de Aragón y Mallorca des de Jaime I a la muerte de Juan II, "Folia Parisiensia", 1 (1983), pp. 40-50.

${ }^{36}$ En el mateix sentit, en suplimir-se l'orde del Temple, "Jaime II se mostró muy particularmente interesado en reunir la documentación de la extinguida milicia y procuró que fuera escrupulosamente entregada a los herederos de sus bienes toda aquella riqueza documental de la Orden del Temple" (Maria Vilar BONET, Datos sobre los archivos del Temple en la Corona de Aragón al extinguirse la Orden, "Martínez Ferrando Archivero. Miscelánea de estudios dedicados a su memoria", Asociación Nacional de Bibliotecarios, Archiveros y Arqueólogos, Madrid, 1968, p. 495).

${ }^{37}$ Jesús Ernesto MarTínez FerRando, El Archivo de la Corona de Aragón, ed. Aymà, Barcelona, 1944, pàgs. 36-37.

${ }^{38}$ Gabriella OLla REPETTO, La politica archivistica di Alfons IV d'Aragona, "XI Congresso de Storia della Corona d'Aragona (Palermo-Trapani-Erice, 1982)", III, Palermo, 1984, p. 463; Francesco CASULA, La cancelleria di Alfonso III il Benigno re d'Aragona (1327-1336), Cedam casa editrice dott. Antonio Milano, Padova, 1967, pp. 19-69.
} 
castlana $^{39}$. Més enllà de la clarificació de les rendes, la mateixa visualització del poder del sobirà en surt enfortida, en imposar la presència reial en cada un dels esglaons de les piràmides castlanes. Coetàniament, els oficis de l'administració central perseveren en les seves tasques, la cancelleria accentua la seva funció, amb la consolidació dels secretaris, i les garanties dels oficials districtuals formalment es confirmen i refermen. Alhora es manté un tènue discurs sobre la pau i treva i s'accentuen algunes disputes amb diferents senyors respecte de la capacitat jurisdiccional, revivint la disquisició entre el mer i mixt imperi en les discrepàncies existents en indrets com el Cabrerès, la pallaresa baronia de Bellera o els dominis, en la zona gironina, dels Senesterra, els Cartellà i els Cruilles.

El llarg regnat de Pere III (1336-1387) travessa molt diverses circumstàncies en les quals l'afany de consolidació del poder reial haurà d'inserir-se amb una varietat d'accions i d'intensitat. D'antuvi, l'atenció per les rendes d'arrel castlana continua a través d'algunes actuacions dels ordinaris territorials $\mathrm{i}$ de diverses comissions, que repassen situacions anteriors i apamen nous indrets, emmarcant-se, en definitiva, entre les competències pròpies d'un batlle general designat, significativament, com a "baiulus generalis et procurator suorum feudorum Catalonie". La constatació de l'evolució rendista de les castlanies, en les que la imatge del poder reial sovint es va difuminant, esperona el monarca a trabar les tinences castrals a costum d'Espanya $a^{40}$, intent, però, que, llevat de casos concretes, sols als comtats de Rosselló i Cerdanya ${ }^{41}$ troba un marc possible arran de la renovació d'oficis que seguí a la presa militar del regne de Mallorca el 1344, per bé que, en aquestes mateixes contrades, la nova fórmula -sota $\operatorname{sou}^{42} \mathrm{i}$ designació reial ${ }^{43}$ - també coneixerà disfuncions i descurances ${ }^{44}$.

\footnotetext{
${ }^{39}$ Flocel SABATÉ, Les castlanies i la comissió reial de 1328, "Estudios sobre renta, fiscalidad y finanzas en la Cataluña bajomedieval", Manuel SÁNCHEZ, comp., CSIC, Barcelona, 1993, pp. 177-241; Flocel SABATÉ, Fiscalitat i feudalisme (Tàrrega, 1328: recompte i reestructuració), Rafael Dalmau editor, Barcelona, 1991.

${ }^{40}$ Ramon d'ABADAL I DE Vinyals, Las "Partidas" a Catalunya durant l'Edat Mitjana, "Dels visigots als catalans", vol. II, Edicions 62, Barcelona, 1970, p. 379.

${ }^{41}$ Pere Català I Roca, Decadència i moment actual dels castells, "Castells Catalans", I, Rafael Dalmau editor, Barcelona, 1990, p. 252.

${ }^{42}$ ADPO 1B-186, fol. $1 \mathrm{r}$.

${ }^{43}$ ACA, Cancelleria, reg. 975, fol. $43 \mathrm{r}$.

${ }^{44}$ ADPO 1B-219, fols. $107 v-108 r$.
} 
Pere III reprèn la preocupació per encertar una administració intermèdia, organitzant l'espai vicarial català, el 1344, en tres governacions Barcelona, Girona, Lleida-, inviables, però, des de la duplicitat denunciada per una administració territorial creixentment mediatitzada pels poders locals i havent de cenyir-se, el 1347, a la figura unipersonal d'alta delegació del sobirà, tot aprofitant, però, que l'administració central -cancelleria, tresoreria, batllia general, mestre racional- s'aferma com a eficaç i burocràtica canalització del poder reial $^{45}$, amb el mateix esperit que s'endreça l'àmbit privat del monarca ${ }^{46}$. Dins d'aquest esquema, l'arxiu del sobirà és objecte d'acurada atenció, amb un fons -"instrumentis, scripturis et registris qui in archivo nostro regio Barchinone recondita sunt "47- emprat en la disputa jurisdiccional i rendística. Precisament, a batllia general els memorials i els capbreus són utilitzats per les comissions indagadores, que n'actualitzen les dades o n'elaboren de nous des de l'afany de "capbrevar tots feus e favaters qui hi sien" 48 i de dilucidar la situació a partir del "libre del possessori dels feus, rendes (...) e delmes que.s reben en Cathalunya e són del patrimoni del senyor rey"49. Aquest aprofita les clarificacions de rendes $\mathrm{i}$ jurisdicció per a recordar les vies d'accés assolides pels antecessors sobre diferents àmbits baronials, com fa el $1352 \mathrm{amb}$ el comtat d'Urgell. Fins i tot més enllà dels drets concrets, el monarca vol fer valer el reconeixement de la seva plena capacitat com a sobirà, incloent-hi allà on hi manca de jurisdicció, com accepta, el 1351, Marquesa de Pinós en retre-li "homagium et iuramentum fidelitatis et quecumque alie que pro eisdem facere debemus eo modo et conditione quo alii nobiles et barones Catalonie facient de locis franchis, immunibus et alodiariis et que non tenentur in feudum pro dicto domino rege"50.

\footnotetext{
${ }^{45}$ Ramon d'ABadal, Pere el Cerimoniós i els inicis de la decadència política de Catalunya, Edicions Destino-Edicions 62, Barcelona, 1986, p. 258.

${ }^{46}$ Próspero de Bofarull, Procesos de las Antiguas Cortes y Parlamentos de Cataluña, Aragón y Valencia, "Colección de Documentos Inéditos del Archivo General de la Corona de Aragón", V, Establecimiento litográfico y tipográfico de D. José Eusebio Monfort, Barcelona, 1850 , pp. 7-316.

${ }^{47} \mathrm{ACA}$, Cancelleria, reg. 1060 , fol. $186 \mathrm{r}$.

${ }^{48}$ ACA, Batllia General 25, fol. 3 r.

${ }^{49}$ ACA, Batllia General 17, fol. $1 \mathrm{r}$.

${ }^{50}$ Joan SERRA I VILARÓ, Baronies de Pinós i Mataplana. Investigació als seus arxius, I, Centre d'Estudis Baganesos, Bagà, 1989, p. 146.
} 
De tota manera, el sobirà manté l'afany per imposar el conjunt de competències que, com a regalies, pretén fer respectar com a matèria exclusivament reial arreu del territori. Se'n surt favorablement, malgrat les tensions palesades en determinats àmbits baronials, en la capacitat d'aprovar fires i mercats, i també en la persecució dels delictes de falsificació de moneda, tot i l'escassa presència d'aquests delictes en comparació amb inicis del segle, essent estèrils, en la pràctica, les exigències sobre les cr,mpetències en el respecte de camins i cursos d'aigua. La força que es podria derivar d'uns Usatges de Barcelona que precisament defineixen la capacitat del princeps terrae, en realitat es limita a la proclamació del Princeps Namque, acceptat sempre amb reticències, i a ocasionals i molt apamades convocatòries del Simili modo amb l'excusa de posar pau inter enemicos. Precisament, traspassat el darrer quart de segle augmenta l'ofensiva per a imposar una capacitat d'actuació dins d'espais baronials. S'aprofiten situacions concretes per exposar les competències exclusives de la corona, com punir barons, segons es pretén, el 1379, al comtat d'Urgell, i es reprèn la insistència en les constitucions de pau i treva com a compendi de les garanties legals de la població que el monarca ha de imposar i fer respectar arreu del país, pretensió, però, que col.lideix amb l'oposició dels nobles que argumenten una tradició contrària, documentant fins i tot anteriors concessions reials, com fa el comte d'Urgell. Semblantment, l'Església rebutjarà l'intent d'intervenció reial en l'àmbit eclesiàstic rera la invocació de les constitucions de pau i treva. L'altre recurs legal que pot argumentar la corona per a tractar de franquejar els dominis baronials, consistent en erigirse en garant del compliment de les constitucions, encara que sigui com a delegació de les mateixes Corts sobre els oficials reials, sols serà invocat en moments molt concrets, relacionats amb peremptòries necessitats ${ }^{51}$.

La reiteració del recurs a puncions fiscals extraordinàries i globals aprovades en corts generals contribueix a afermar la visió unitària del país entorn de la corona, bo i més quan els requeriments organitzatius empren la

\footnotetext{
${ }^{51} \mathrm{El} \mathrm{1364}$, en les corts convocades a Barcelona per a reunir forces destinades a socórrer la ciutat de València assatjada per les tropes castellanes, Pere III especifica al veguer de Tortosa i Ribera d'Ebre que la recollida de les "forces e destrenyements en los lochs nostres e en los altres en los quals (...) havem acustumat de forçar façats per auctoritat nostra e en los lochs en los quals no havem acustumat de forçar ne són nostres se faça per auctoritat dels senyors dels dits locs a requesta vostra si fer o volran, en altra manera fer no u volran que u ffaçats vós per auctoritat e comissió de la present Cort, la qual comissió la dita Cort ab tenor de la present vos fa sobre les dites coses" (ACA, Cancelleria, reg. 1404, fol. 27 v).
} 
xarxa vicarial reial sobre el conjunt de Catalunya. El desembocament d'aquest tractament exactor extraordinari en un sistema fiscal estable i global -prenent com a fita l'establiment de les generalitats en les corts de 1365permet parlar d'una fiscalitat d'estat ${ }^{52} \mathrm{i}$, coherentment, afermar el lloc de qui, com a monarca, n'ocupa la presidència.

En darrer terme, la base del poder reial continua radicant en garantir les pròpies vies d'obtenció de renda i de possessió de jurisdicció. Des d'aquesta convicció, la constatació dels perjudicis tant fiscals com jurisdiccionals derivats del fort deteriorament del patrimoni reial ${ }^{53}$, preocupa al monarca $^{54}$-"ens sab greu lo disminuïment de nostre patrimoni"55 - i el menen a promoure la reintegració dels dominis alienats sota carta de gràcia mitjançant l'aportació econòmica dels propis habitants dels llocs afectats. La fórmula, desenvolupada en diversos indrets en els anys 60 i 70 i idèntica a la que el 1377 l'infant Martí aplica sobre tot el seu comtat de Besalú, s'accelera vers 1382 i esdevé una actuació programàtica a partir de 1384 , incentivada per les grans viles i ciutats, que aconsellen l'operació als indrets situats dins del seu radi de capitalitat, tot oferint-los garanties amb fórmules com el carreratge ${ }^{56}$.

El regnat de Joan I (1387-1396) assumeix una certa continuïtat d'afanys. Des del primer moment, i resseguint estratègies ja elaborades prèviament, pretén intervenir dins d'àmbits nobiliaris gràcies a proclamar l'exclusiva capacitat respecte a l'autorització de talles i imposicions en tots els municipis, inclosos els baronials. La mesura, concordant amb el raonament romanista segons el qual tot el fisc només pertany al príncep, s'imposa en moltes senyories eclesiàstiques -els dominis del bisbe d'Urgelli en importants àmbits baronials -el vescomtat de Castellbò-, inclosos alguns,

\footnotetext{
${ }^{52}$ Manuel SÁNCHEZ, El naixement de la fiscalitat d'Estat a Catalunya (segles XII-XIV), Eumo Editorial-Universitat de Girona, Vic, Osona, 1995, pp. 132-135.

${ }^{53}$ Jordi VALLĖS-Jordi VIDAL-Maria Carme COLL-Josep Maria BosCH, El Llibre Verd de Vilafranca, II, Fundació Noguera, Barcelona, 1992, pp. 78-79.

${ }^{54}$ AHCTE, Paeria i Vegueria II, 59, fol. 129 v; ADPO 1B-205, pergamí 1380.

${ }^{55}$ ACA, Cancelleria, reg. 1560, fol. 36 v.

${ }^{56} \mathrm{~L}$ 'operació, per l'enrenou dels tractes, assoleix un cert ressò a les demarcacions de Girona, Penedès, Vallès, Moianès i Barcelona, amb el respectiu suport dels governs municipals de Girona, de Vilafranca del Penedès i, per a les tres darreres demarcacions, de Barcelona. Ben mins és l'efecte obtingut a Osona i a Conflent i encara menor al Berguedà, Bages i Camprodon, essent poc més que testimonial la intervenció a les vegueries de Rosselló, Cervera i la Vall de Ribes. En la resta, pràcticament no es va arribar a encetar l'actuació.
} 
com la baronia de Pinós, que podien documentar la pràctica, a inicis del mateix segle XIV, d'una plena capacitat pròpia al marge del monarca. De fet, la invocació de les matèries que "se pertanyen de dret comú al Senyor Rey" permet exigir el respecte a les regalies, reclamant, puntualment segons com es presentin les ocasions, l'exclusiva capacitat sobre els actes maritims, el tracte de vagabunts e estrangers, la jurisdicció sobre los camins públichs, la protecció viudarum, pupillorum et miserabilium personarum o, a:nb majors resultats, les concessions de fires i mercats i l'autorització d'erigir fortaleses, a la qual es plega, per exemple, el vescomte de Cabrera el 1392. Es recordarà, a la vegada, el domini superior reial sobre les aljames situades en àmbit baronial, tot i que restarà, però, força diluït en la pràctica.

Es manté, igualment, tant la incentivació del batlle general i el recurs a comissions específiques per a inspeccionar la percepció de lluïsmes i evitar l'esmicolament de la renda per raó de males gestions i de la incúria de detentors i castlans ${ }^{57}$, com el control econòmic de l'actuació de batlles $i$, sobretot, veguers, perseguint una obtenció de guanys de les corts territorials que ja resultà difícil per a Pere III. La continuittat més plena es segueix en el moviment de redempció de jurisdiccions. Joan I, que ja se n'ocupava com a governador general en vida del seu pare, continua la mateixa via al llarg de tot el regnat. L'interès palesat per la corona -designarà comissaris específics que faran causa comuna amb el batlle general "ad luendum seu redimendum ac nostro Regio patrimonio resarciendum et reintegrandum" i delegats concrets per a les vegueries centrals i orientals del país- s'ajusta, en realitat, a un fort pes de les capitals regionals sobre la demarcació, amb actuacions destacades com les protagonitzades, sobretot, per Girona, seguida, a certa distància, per Vic i Barcelona ${ }^{58}$. La dinàmica, amanida per encoratjadores paraules d'un monarca que reiteradament es confesa delerós de recuperar el patrimoni ${ }^{59}$-"desitjans que les jurediccions e drets reyals venuts e alienats a Cathalunya migençant carta de gràcia tornen a nostre

\footnotetext{
${ }^{57} \mathrm{El} 1395$ el monarca adverteix al batlle general que "diversa castra, domus, census, decima et lezde infra Cathalonie principatum existant que ad directum dominium pro nobis tenentur et in eisdem nullum censum seu servicium recipiamus seu habeamus" (ACA, Cancelleria, reg. 2009. fol. $45 \mathrm{v}$ ).

${ }^{58}$ Més concreta és l'actuació a Berga, obtenint també alguns resultats al Penedès, amb una intervenció ben específica a la vegueria de Cervera, alhora que Camprodon i Besalú participen, amb minsos resultats, de l'empenta gironina i es tracta d'incidir de manera puntual al Pallars, no assolint més que una presència merament testimonial en demarcacions com Tàrrega.
}

${ }^{59}$ ADPO 1B-205, pergamí 1387; ACA, Cancelleria, reg. 1802, fol. $56 \mathrm{r}$. 
patrimoni e la nostra cosa pública"60 -ha estat ignorada per la historiografia fins al present ${ }^{61}$, cosa ben lògica, perquè els indicadors més cridaners del moment no són la lentitud amb què avancen les negociacions per a reintegrar el patrimoni ni la migradesa dels resultats en proporció amb l'energia esmerçada, sinó l'evidència que allò que es recupera és superat pel que, coetàniament, s'està alienant. El panorama no és d'enfortiment sinó d'afebliment. Per damunt de totes les actuacions, l'afany d'afermament del poder reial sembla naufragar entre dificultats, impotent i ineficaç en front del topall de l'adversitat ${ }^{62}$.

\section{DifiCULTATS I TOPALLS EN LA PRETENSIÓ REIAL: L'ESTAT REAL DEL PODER}

Totes les mesures endegades requereixen, per tal de complir llur objectiu, disposar de l'adient força, i la força del sobirà està en funció dels seus recursos. Precisament la monarquia catalana entra en el segle XIV procedent d'una centúria on ha palesat una perenne dificultat econòmica ${ }^{63}$, justificant plenament l'interès de Jaume II tant per clarificar les pròpies rendes com per augmentar les bases patrimonials d'on extreure renda $\mathrm{i}$ jurisdicció. Les mesures reials, però, no capgiraran la situació, ans al contrari, perquè el segle XIV accentuarà les exigències en matèria exterior (preparatius contra Almeria -1309-, l'anada a Sardenya -1321-1324-, la campanya de Granada-1329-1334- l'atenció a l'Estret de Tarifa en temor als

\footnotetext{
${ }^{60} \mathrm{ACA}$, Cancelleria, reg. 2024, fol. 28 r.

${ }^{61}$ Semblantment l'encara menor ressò d'aquesta operació a Aragó i a València sols ha estat estudiat en casos concrets, com la redempció de la jurisdicció d'Onda (ACA, Cancelleria, reg. 2024, fols. 91 v - 96 r; $97 \mathrm{r}-102 \mathrm{r}$, entre d'altres), tractada bàsicament des de la documentació valenciana a: Enric GUINOT, Un precedent en la recuperació del patrimoni reial al País Valencià: la jurisdicció d'Onda, 1393, "Saitabi", XXXVI (1986), pp. 143-146.

${ }^{62}$ Es la coneguda percepció adreçada al monarca per la ciutat de València: Joseph $\mathbf{M}^{\mathbf{a}}$ Roca, Memorial de greuges que'ls missatgers de la Ciutat de Valencia presentaren al Rey Johan I d'Aragó, "Boletín de la Real Academia de Buenas Letras", XI (1924), pp. 70-79.

${ }^{63}$ Ferran VALLS TABERNER, Els sobrenoms dels reis Anfós II $i$ Anfós III, "Estudis Universitaris Catalans", IX (1915-1916), pp. 102-103; J. N. HILlgarTh, The Problem of $a$ Catalan Mediterranean Empire 1229-1327, "The English Historial Review", Supplement 8 (1975), p. 9; Montserrat SANMARTí, El patrimoni reial a Catalunya durant els anys 1286-1289, "XI Congresso di Storia della Corona d'Aragona", IV, Palermo, 1984, pp. 217-218; Stephen P. BENSCH, La primera crisis bancaria de Barcelona, "Anuario de Estudios Medievales", 19 (1989), pp. 321-327.
} 
benimerins -1340-1344-, la lluita pel regne de Mallorca -1343-1344-, la guerra amb Castella -1356-1369-, el recurrent conflicte amb Gènova -13301378-, encadenat al problema sard -1347-1420-, tensions amb Granada 1390-1394), sumades a les necessitats en el regiment intern (amb episodis com l'anada contra Empúries el 1385 i les reiterades invasions septentrionals durant la segona meitat de la centúria). El difícil part d'un sistema fiscal propi, amb la incapacitat d'uns recursos ordinaris minvats per les mateix.es concessions reials i plenament superats per les puncions extraordinàries de manera galopant des del regnat d'Alfons el Benigne, evidencia les necessitats de la corona, insadollables malgrat l'elevat pes de la creixent exigència fiscal en un context de globals dificultats sòcio-econòmiques. En aquesta situació, el recurs a desprendre's del propi patrimoni, continuant la pràctica dotzentista, ja ha de ser utilitzat per Jaume II en la seva primera dècada de regnat, havent, més endavant, d'accentuar-lo per a finançar les campanyes exteriors importants. L'avenç del segle no farà més que incrementar aquesta tònica, sota la fórmula de les cessions a carta de gràcia, cedint tota la jurisdicció, de manera molt greu en els regnats de Pere III -a la Cancelleria requereix una sèrie documental pròpia des de 1342- $\mathrm{i}$, portada ja al paroxisme, de Joan I: el 1392 aquest monarca sols exerceix la plena capacitat jurisdiccional sobre un $13^{\prime} 43 \%$ del territori i un $22{ }^{\prime} 17 \%$ de la població. Significativament, el mateix sobirà català duu impregnada la imatge de pobresa: tant Jaume II com Joan I hauran de posar en venda les seves corones, i també Pere III, que a la vegada s'acostuma a tenir empenyorada l'única vaixella de luxe, mentre que les dificultats econòmiques per sebollir dignament al monarca sorgiran no sols amb Joan I sinó també amb el rei Martí.

En aquest context, difícilment el monarca pot capgirar al seu favor un panorama del poder que entra en el segle XIV procedent d'una centúria on sovint el rei ha hagut de transigir davant de la capacitat superior dels barons i davant de l'emergència dels municipis, tal com es sanciona en la penúltima dècada ${ }^{64}$. Els nobles, superant les primeres interpretacions

\footnotetext{
${ }^{64}$ José Luís MARTín, Pactismo político y consolidación señorial en Cataluña tras la conquista de Sicilia, "Economía y Sociedad en los reinos hispánicos de la Baja Edad Media", vol. I, El Albir, Barcelona, 1983, p. 251.
} 
romanistes del poder reial ${ }^{65}$, han blindat l'autonomia jurisdiccional en les corts de 1228, $1275 \mathrm{i}$, ja definitivament en imposar les situacions de fet, de 1283, alhora que la seva força els permet impedir l'assentament de qualsevol precedent en sentit contrari i sostenir disputes reivindicant una interpretació plena de les pròpies capacitats. Jurisdiccionalment, doncs, el país és una juxtaposició d'espais impenetrables, amb una inherent obstrucció i manca de col.laboració. La veritable impunitat que se'n deriva forma part del sistema: el mateix monarca, el 1382, incentiva el creixement demogràfic de les seves viles de Cervera i Vilafranca del Penedès garantint impunitat a tots els qui hagin delinquit en un altre domini.

Aquest plantejament bloqueja l'actuació dels oficials ordinaris i, corolàriament, lesiona l'autoritat règia de la que són portadors. La situació s'agreuja amb l'augment de les cessions reials, i encara més en produir-se en moments sòcio-econòmicament difícils, perquè la creixent fragmentació jurisdiccional de les diferents regions comportarà greus problemes pels vilatans de la capital sòcio-econòmica, en tant que els delictes comesos en la vila poden esdevenir impunes $i$, sobretot, els molts crèdits no tornats poden ser molt difícilment exigits. El trontollament de fortunes urbanes per aquesta raó, en ciutats com Girona o Manresa, posa en evidencia quins són els dos pols de poder que col.lideixen: el baronial i el municipal. Ambdós es disputen el control i la renda de la regió. I ambdós gaudeixen d'una potència absent en el monarca. Els dominis nobiliaris no dubten en aplicar mesures expeditives, des de la intimidació a l'ús d'una força a la que invoquen tenir dret pel propi caire militar, podent ignorar les Constitucions i atorgar protecció als súbdits estenent la fórmula dels guiatges, titllada d'abusiva per uns però, per altres, preferible a les garanties reials. Alhora, les oligarquies urbanes es projecten sobre la regió immediata adquirint-hi propietats, rendes i drets fins i tot jurisdiccionals, mentre la ruralia empra la capital com a centre de serveis. Aquesta mateixa imbricació exigeix una estabilitat jurisdiccional, que col.lideix amb la capacitat baronial. La barreja inherent a la relació -burgesos posseint jurisdicció, barons residint en viles...- no aproparà postures, ans el contrari, com evidenciaran les tensions

\footnotetext{
${ }^{65}$ Aquilino IgLESIA Ferreirós, El cartulario de Sant Cugat del Vallés: del "Liber Iudiciorum" al "Corpus Iuris Civilis", "I Seminario de Historia del Derecho y Derecho Privado. Nuevas técnicas de investigación", Joaquin CERDÁ y RUIZ-FunES - Pablo SALVADOR CODERCH, eds., Universidad Autónoma de Barcelona, Bellaterra, 1985, p. 166.
} 
de la segona meitat del segle XIV arran de la presència dels homes de paratge en els nuclis urbans.

El monarca, mancat de força efectiva, jugarà entre les pressions dels uns i dels altres, per bé que els municipis reials pretendran identificar els propis interessos amb els del sobirà. No pas casualment, les demarcacions vicarials reials surten del segle XIII coincidents amb els radis de capitalitat sòcio-econòmica de les respectives seus, remembrant un Jaume I pressiona، pels nobles que imagina que ciutadans i eclesiàstics són més grats a l'esguard $\operatorname{divi}^{66}$. De fet, el seu nét, Jaume II, tot i viure tensions amb l'estament eclesiàstic $^{67}$, sovint pren aquest com aliat contra la puixança baronial. El poder clerical, però, ajudarà el monarca allà on hi concordi, oposant-s'hi en altres casos, com és clar quan les comissions endreçadores del patrimoni li són adverses o en les tensions sorgides entorn de les notaries. En realitat, el comportament baronial d'alts eclesiàstics per una banda $i$, per altra, la particularitat estamental, amb el problema dels clergues conjugats i la difícil combinació, a nivell fiscal i jurisdiccional, entre l'església secular i els àmbits municipals, obren escletxes de tensió que centren la disputa pel poder, sobretot, en els dos pols més puixants: el poder baronial i el poder municipal ${ }^{68}$.

\section{LA FORÇA MUNICIPAL I EL PODER REIAL}

La recerca de l'estabilitat jurisdiccional impulsa les capitals regionals inserides en àmbits baronials a exigir als seus senyors privilegis d'inalienabilitat, segons fan Balaguer o Castelló d'Empúries, tal com, de manera encara més accentuada, succeeix dins de l'àmbit reial. En aquest, la mateixa feblesa i llunyania del monarca esdevé un al.licient perquè un municipi pròsper prefereixi el seu domini, a part d'afermar les garanties constitucionals i assolir l'accés a fòrums de decisió com el braç regi a les corts.

\footnotetext{
${ }^{66}$ Llibre dels feits del rei en Jaume o Crònica de Jaume I, cap. 498 (Ferran SOLDEVILA, Les quatre grans cròniques, Editorial Selecta, Barcelona, 1983, p. 173).

${ }^{67}$ Odilo ENGELS, Los reyes Jaime II y Alfons IV de Aragón y los concilios provinciales de Tarragona, "VIII Congreso de Historia de la Corona de Aragón (Valencia, 1967)", II, València, 1970, p. 262.

${ }^{68}$ Flocel SABATÉ, El veguer a Catalunya. Anàlisi del funcionament de la jurisdicció reial al segle XIV, Universitat de Barcelona, tesi doctoral inèdita, 1993, pp, 1194-1577.
} 
La identificació entre el radi d'influència del municipi i la demarcació reial -el govern local adopta decisions que afecten tota la regió, esmerça sumes per a evitar la fragmentació jurisdiccional i imbricar jurídicament els diferents indrets, alhora que sovint aquests cerquen el seu aixopluc i el monarca s'adreça a ell per als afers que afecten tota la demarcació- incentiva la mediatització de l'oficial districtual, tant assolint determinats reconeixements d'intervenció com incidint en el seu nomenament, la seva actuació i institucionalitzant l'acceptació de l'accés al càrrec i del posterior control de l'exercici. L'ús de l'oficial districtual implica l'aprehensió del poder reial inherent. Es pretén, per tant, infondre el prestigi del monarca als interessos municipals. Des d'aquest objectiu, el municipi entén beneficiosa la identificació amb el sobirà, fomentant-la en tots els sentits, fins i tot els anímics, a través d'invocar una identificació amb els planys i les joies de l'esdevenir familiar del rei ${ }^{69}$, ben canalitzada mitjançant les afalalagadores expressions representatives ${ }^{70}$.

La postura municipal implica, alhora, el desig d'encertar una concepció elaborada i estable de la jurisdicció reial, aliena al caprici del monarca. De fet, els poders locals expressen una forta malfiança vers un rei que, empentat per les imperioses necessitats econòmiques, s'aboca ${ }_{2}$ de manera creixent en la segona meitat de la centúria, a cercar quantioses injeccions crematístiques mitjançant tant una abusiva interferència amb la justícia ordinària, en concedir canvis de fur, llicències, guiatges i remissions, com el recurs a una veritable fiscalitat encoberta mitjançant concessions a municipis -guiatges i sobretot remissions- que comporten importants exigències econòmiques. Aquestes recauran sobre un erari ja prou espletat per les reiterades puncions extraordinàries del mateix monarca, qui no deixa, al mateix temps, de promoure una elevada despesa en l'emmurallament de totes les viles i ciutats, les quals, en un context sòcio-economicament difícil, s'enfonsen en el permanent $i$ irreversible llast del deute públic. Per això, des dels municipis, el rei és greument titllat d'extorquidor aliè als interessos locals, tant per imposar contribucions sufragadores d'empreses bèl.liques sovint alienes a la comprensió popular com per ser considerat el responsable de la incapacitat i impunitat judicial i de la crisi econòmica, en barrar

\footnotetext{
${ }^{69}$ Flocel SABATÉ, Lo senyor rei és mort!, Publicacions de la Universitat de Lleida, Lleida, 1994, pp. 247-273.

${ }^{70}$ Francesc MASSIP, El rei $i$ la festa. El ritu de la propaganda, "Revista de Catalunya", 84 (1984), pp. 63-80.
} 
l'actuació dels seus ordinaris, agredir fiscalment la població, propiciar la fragmentació jurisdiccional i, encara, afavorir puntualment interessos baronials ${ }^{71}$.

Davant d'això, el municipi, projectant els seus interessos sobre la regió i apropant-se l'oficial districtual del monarca, invoca la seva identificació amb el poder reial tot fent-ne una interpretació estable, centrada en el respecte a les Constitucions de Catalunya, amb les Constitucions de Pau $j$ Treva, els Usatges de Barcelona i els privilegis locals. Coherentment, són les viles i ciutats, sobretot si són grans com Barcelona o Girona, qui, en les darreres dècades del segle XIV, invoquen no sols la legislació constitucional sinó els conceptes de jurisdicció reial i de regalies per a corregir al mateix monarca quan no s'hi ajusta ${ }^{72}$.

Des d'aquesta posició, els grans municipis, en els últims anys del segle, empenyen Martí I a prosseguir i culminar l'operació de redempcions jurisdiccionals que, sostinguda en gran part per ells mateixos, s'esllanguia des de $1384^{73}$. Significativament, en revertir el 1402 el comtat d'Empúries a la corona, la ciutat de Girona s'esforça, invocant els guanys per a la corona reial $^{74}$, en convèncer el monarca per a aplicar-hi el programa de redempcions, contra el parer de l'aristocràcia i la burgesia del comtat que prefereixen mantenir el tracte baronial. El sobirà concordarà, finalment, amb aquests i no pas amb els qui proclamen la defensa de la jurisdicció reial ${ }^{75}$, remembrant l'opció presa, sota altres condicionants, a la baronia de Lluçà, on també havia triat la postura nobiliària, contrariant el govern municipal

\footnotetext{
${ }^{71}$ Flocel SABATÉ, L'augment de l'exigència fiscal en els municipis catalans al segle XIV: elements de pressió $i$ de resposta, "Col.loqui Municipi i fiscalitat a la baixa edat mitjana (Lleida, 1995)", Institut d'Estudis Ilerdencs, Lleida, (en premsa).

${ }^{72}$ Flocel SABATÉ, El poder reial entre el poder baronial $i$ el poder municipal, "XV Congrés d'Història de la Corona d'Aragó (Jaca, 1993)", Diputación General de Aragón, Zaragoza (en premsa).

${ }^{73} \mathrm{El}$ protagonisme municipal de les seus vicarials com a capitals regionals i la sincronització de les redempcions finiseculars com a culminació de la línia endegada un quart de segle abans complementen el molt acurat estudi realitzat des del vessant reial (Maria Teresa FERRER I MALLOL, El patrimoni reial i la recuperació dels senyorius jurisdiccionals en els estats catalano-aragonesos a la fi del segle XIV., "Anuario de Estudios Medievales", 7 [1970-1971], pp. 351-492).

${ }^{74}$ AHCG XV.4, lligall 2, llibre 3, sense numerar.

${ }^{75}$ Flocel SABATÉ, Castelló d'Empúries, capital del comtat d'Empúries baixmedieval (en premsa).
} 
vigatà que actuava reivindicant els beneficis per a la corona i la jurisdicció reial $^{76}$.

En realitat, el monarca també tem la puixança dels grans municipis, a la vegada que li pot resultar més rentable un tracte puntual amb barons malgrat que això comporti menysprear esforços populars esmerçats per la causa reial, com succeí a Lluçà ${ }^{77}$. El comportament, en definitiva, denota que el sobirà haurà de continuar movent-se entre el poder municipal i el baronial. La pressió del primer sobre els oficials districtuals contribueix, de fet, a desprestigiar-los abans de la fi de la centúria, forçant el monarca a encertar figures d'intervenció extraordinària de major eficàcia, com seran, més enllà dels comissaris i els algutzirs -rebutjats pels governs locals-, els virreis presents en vegueries conflictives ja entrant al segle XV.

\section{L'EQUILIBRI FINAL}

En aquesta dinàmica, el poder municipal mostra la seva ambivalència. Internament només es deu als grups dirigents de cada població, $\mathrm{i}$ si els interessos particulars o col.lectius es veuen amenaçats s'exercirà la pròpia força, no dubtant en arribar, en cas de fadiga de dret, a les marques i al sometent, sota la presidència del respectiu oficial jurisdiccional. Aquest exercici encararà, en els enfrontaments entre nuclis urbans, uns oficials reials contra homòlegs igualment reials, deixant sense efecte els esforços de Pere III per a tractar de motivar la col.laboració a tenor de la identitat de jurisdiccióo $^{78}$. A la vegada, la coincidència en el perfil de privilegis comunament desitjats i la concordança en uns mateixos afanys exteriors imposa una imatge similar entre els diversos municipis ${ }^{79}$, donant cos real al brachio regis, sota influència, però, de les ciutats i viles més prestigioses, veritables capdavanteres no sols en els principals afers polítics ${ }^{80}$ sinó també en els

\footnotetext{
${ }^{76}$ AHMV, llibre de Privilegis X, pergamí 192.

${ }^{77}$ Antoni Pladevall-Pere Català, Castell de Lluçà, "Els Castells Catalans", IV, Rafael Dalmau editor, Barcelona, 1973, p. 813.

${ }^{78} \mathrm{AHCT}$, Llibre del batlle 1, fol. $10 \mathrm{r}$.

${ }^{79}$ Es pot apreciar fins $\mathrm{i}$ tot una coincidència entre els principals privilegis que locorum regalium Catalonie possident et gauderent (AHS, pergamí 16 E 1).

${ }^{80}$ Santiago SOBREQUÉS I VIDAL, La petita noblesa catalana $i$ l'interregne de 1410-1412, "Estudis d'Història Medieval", III (1970), pp. 88-91.
} 
més formals. L'ascensió d'aquestes línies mena a un segle XV on el poder municipal -malgrat $\mathrm{i}$ mitjançant el propi clivellament intern ${ }^{81}$ - no sols esdevé altament protagonista en episodis com el Compromís de Casp o la guerra civil sinó que posa en evidència que la conceptualització del poder sorgida dels àmbits locals, centrada en una percepció comuna sustentada per un mateix conjunt normatiu i de comportament, ha contribuït a la visió unitària de Catalunya, fins i tot al marge del monarca ${ }^{82}$.

Semblantment, els plantejaments jurisdiccionals consolidats pel poder baronial en el segle XIV obtenen també el seu reflex en la quinzena centúria. En un moment òptim pel patrimoni reial com és el 1414, quan tot just s'ha incorporat el comtat d'Urgell i són recents les importants reintegracions en l'espai gironí, la jurisdicció reial no sobrepassa el 27 ' $87 \%$ del territori i el $30 \%$ de la població ${ }^{83}$. Els grans dominis baronials es mantenen intactes. Fins i tot alguns es recuperaran -el comtat d'Empúries- o s'envigoriran -el comtat de Cardona, convertit en ducat el 1491, acomboiat pel també enfortit marquesat de Pallars i el comtat de Prades-. Com a tret ben característic, la fragmentació jurisdiccional, accentuada amb les cessions patrimonials produïdes en la quatorzena centúria, consoliden la imatge del país que sorprendrà els viatgers del segle XVI, els quals aprecien l'arrel de la inestabilitat bandolera en l'elevada presència de "señores (que) poseen lugares y castillos sobre los que no tiene autoridad el Rey, y a dichos lugares se acogen todos los asesinos a quienes ellos, por tener más séquito, entretienen, nutren y defienden" ${ }^{84}$.

Tot plegat reflecteix com es visqué, en l'escenari català, la tensió entre l'enlairament romanista del tron i la noció tradicional de reialesa. El concepte ideal de monarquia, al llarg de l'Edat mitjana, es situa en el correcte regiment efectuat per un governant que ha de guiar-se per unes

\footnotetext{
${ }^{81}$ Jaume VICENS VIVES, Els Trastàmares (segle XV), Editorial Vicens Vives, Barcelona, 1988, pp. 32-49.

${ }^{82}$ Flocel SABATÉ, El territori de la Catalunya medieval, Fundació Salvador Vives Casajuana, Barcelona (en premsa).

${ }^{83}$ Es pot apreciar cartogràficament l'evolució de la jurisdicció reial entre el 1322, el 1392 i el 1414, a manera de tres moments emblemàtics, a: Flocel SABATÉ, Rei $i$ Cort. El patrimoni reial, Víctor HuRTADO-Jesús Mestre, dirs., Atles Històric de Catalunya, Edicions 62, Barcelona, 1995, p. 107.

${ }^{84}$ Francesco Guicciardini, Viaje a España, José Maria Alonso Gamo ed., Editorial Castalia, Valencia, 1952, p. 39.
} 
virtuts morals ${ }^{85}$ assumint el deure de perseguir el bonum commune $e^{86}$. Així, malgrat la marxa vers la concentració en la sobirania reial ${ }^{87}$, es limiten les pretensions que, des del recuperat dret romà ${ }^{88}$, aspiren a "la independència del príncep davant de les lleis"89 i es manté que, en realitat, "le pouvoir absolu, sans aucune limitation, est contraire à la loi divine, aux intérêts des princes et de leurs royaumes" 90 . Situat en el context català del segle XIV, el dilema contraposa Pere III, que el 1380 proclama que respectarà les lleis si et in quantum volumus ${ }^{91}$, amb Francesc Eiximenis, que limita la figura del sobirà ${ }^{92}$ al regidor acceptat per la comunitat, la qual no cedeix "la potestat absolutament a negun sobre si mateixa, sinó ab certs pactes e lleis"93.

\footnotetext{
${ }^{85}$ Michel SENELLART, Les arts de gouverner. Du regimen médiéval au concept de gouvernement, Editions du Seuil, Paris, 1994, pp. 20-21.

${ }^{86}$ Edelgard DU BRUCK, Grandes esperances, grandes illusions: les princes dans la littérature allemande du XVe siècle, "Le pouvoir monarchique et ses supports idéologiques aux XIVeXVIIe siècles", Publications de la Sorbonne Nouvelle, Paris, 1990, p. 209.

${ }^{87}$ José Manuel NIETO SORIA, Ideología y centralización política en la crisis bajomedieval. Vías de aproximación y dificultades interpretativas, "Historia a Debate. Medieval", Carlos Barros, ed., Santiago de Compostela, 1995, pp. 154-158.

${ }^{88}$ Luis GaRCía De VALDEAvellano, Curso de Historia de las Instituciones españolas, Alianza Universidad Textos, Madrid, 1993, pp. 426-427.

${ }^{89}$ Aquilino IgLESIA FerReIrós, La creació del Dret. Una història de la formació d'un dret estatal espanyol, I, Editoral Gráficas Signo, Barcelona, 1993, pp. 433-434.

${ }^{90} \mathrm{Jean}$ DUfOURNET, Le prince et ses conseillers d'après Philippe de Commynes, "Le pouvoir monarchique et ses supports idéologiques aux XIVe-XVIIe siècles", Publications de la Sorbonne Nouvelle, Paris, 1990, p. 24.

${ }^{91}$ Constitucions y altres Drets de Cathalunya, II, llibre 1, títol X (Departament de Justícia de la Generalitat de Catalunya, Barcelona, 1995, vol. II, p. 37). Sobre aquest aspecte de la plenitudo potestatis a Catalunya, vegeu, de manera compendiada, Jesús LALINDE ABADÍA, Las instituciones de la Corona de Aragón en el siglo XIV, "VIII Congreso de Historia de la Corona de Aragón (València, 1967)", II, València, 1970, p. 20.

92" Llegim que com lo rei d'Aragó en Pere digués a un servidor seu que 'lla va la llei on vol lo rei', respòs un savi hom al rei, qui era present, e dix: 'Hoc, mas no deu ésser rei qui no té la llei e no serve aquella'" (Francesc EIXIMENIS, Dotzè del Crestià, cap. CCCLXIV [Francesc EiXIMENIS, Lo Crestià (Selecció), Albert Hauf, ed., Edicions 62-La Caixa, Barcelona, 1983, p. 199]).

${ }^{93}$ Francesc EIXIMEnIS, Dotzè del Crestià, cap. CLVI (Francesc EIXIMENIS, Lo Crestià (Selecció), Albert Hauf, ed., p. 191). Al respecte, entre altres, vegeu: Angel LóPEZ-AMO MARÍN, El pensamiento político de Eximenis en su tratado de "Regiment de Princeps", "Anuario de Historia del Derecho Español", XVII (1946), pp. 5-139; Marc B. EsColÀ, Sobre la teoría del poder en el tractat de Francesc Eiximenis: "Regiment de la Cosa Pública", "Finestrelles", 6 (1994) pp. 189-204.
} 
El respecte a la llei divina ${ }^{94}$ i a la tradicióos, que durant tot el context medieval acompanyen aquestes reflexions, s'amotllen a la realitat d'un discurs reial pronunciat entre la gran capacitat municipal i el manteniment de la força baronial. La monarquia del segle XV continuarà maldant per la cura de la renda i el patrimoni, cedint i reintegrant dominis jurisdiccionals, cercant situacions propícies a penetrar en àmbits baronials per exigir el respecte de regalies i perseverant en el discurs d'afermament, per bé que l'allunyament finisecular impedirà una culminació exclusivament pròpia de la línia encetada.

\section{EL DISCURS DEL PODER REIAL I L'Elaboració DE LA Història de CATALUNYA}

Ultra la continuïtat de les respectives evolucions en la centúria següent, el discurs entorn del poder reial i la seva resolució en el context del segle XIV s'ha escolat per viaranys tal vegada més subtils. D'antuvi, en un país on, de cara al segles moderns, els jurisconsults jugaran un paper molt important $^{96}$, un discurs basat en el raonament romanista del poder pot assolir un fort ressò, desconnectant fins i tot de la realitat d'on ha sortit. Així, s'ha vingut acceptant fins al present un plantejament en el qual la jurisdicció només correspon al sobirà, el qual pot cedir-ne, sempre per graciosa concessió, la part civil, i en alguns casos també la criminal, servant, però, els indicadors superiors, començant per la capacitat legislativa, indelegable $\mathrm{i}$ incomunicable ${ }^{97}$. La verticalitat d'aquesta imatge, amb el

\footnotetext{
${ }^{94} \mathrm{La}$ fidelitat als dictats cristians esdevé concordant amb la ingerència de Déu en el curs històric (Francisco Elías DE TEJADA, Historia del Pensamiento Político Catalán, I, Ediciones Montejurra, Sevilla, 1963, p. 213), en línia amb el pensament teològic i la percepció comuna del moment.

${ }^{95}$ Encara el 1435 Bernat Fivaller i Pere Santcliment recorden al Magnànim que los fets de Cathalunya tots se regien per eximplis dels passats (Jordi RUBIÓ I BALAGUER, Intentant veure d'aprop Alfons el Magnanim, "Martínez Ferrando Archivero. Miscelánea de estudios dedicados a su memoria", Asociación Nacional de Bibliotecarios, Archiveros y Arqueólogos, Madrid, 1968, p. 450.

${ }^{96}$ Santiago SOBREQUÉS I VIDAL, Història de la producció del Dret Català fins al Decret de Nova Planta, Col.legi Universitari de Girona, Girona, 1978, pp. 78-79.

${ }^{97}$ Tomàs de MONTAGUT, La recepción del derecho feudal común en Cataluña. (Notas para su estudio), Manuel SÁNCHEZ (compilador), "Estudios sobre renta, fiscalidad y finanzas en la Cataluña bajomedieval", CSIC, Barcelona, 1993, pp. 166-167.
} 
monarca presidint la piràmide feudal com a possessor i donador de tota la jurisdicció, ha imposat, més enllà dels resultats pràctics, un llast a un futur allargassat fins als nostres dies, ancorat en la creença en una societat catalana baix-medieval que, tot $\mathrm{i}$ viure tensions significatives, s'endreçaria en l'acceptació de la suprema capacitat reial, imatge que, en realitat, contrasta amb les contundents limitacions de l'actuació règia tant per la impenetrable força baronial ${ }^{98}$ com per la capacitat municipal ${ }^{99}$.

El mateix discurs s'ha beneficiat del posterior curs històric dels segles moderns i d'una historiografia basada preferentment en les fonts reials, podent d'aquesta manera perpetuar la imatge de la dolça senyoria del monarca contraposada a les "moltes oppressions, vecsacions e mals tractaments" propis de l'arbitrarietat baronial ${ }^{100}$ imposada a un poble delerós de la jurisdicció reial ${ }^{101}$, segons el llenguatge oficialista i tòpic ja en el segle XIV, reiterat en l'entorn de Pere III $^{102}$, recordat en el moviment de redempcions sota Martí $\mathrm{I}^{103}$, reprès a la segona meitat del segle XV per Joan II $^{104}$ i grat als grups socialment emergents que en el segle XIX es beneficien de l'agonia del sistema senyorial. S'edulcora així la visió històrica de la monarquia i es simplifica la imatge del domini baronial, malgrat que la realitat congeniava una complexitat prou evidenciada tant en el veïnatge d'indrets que malden per integrar-se en la jurisdicció reial amb altres que tracten d'evitar-la -Sarral i Conesa per posar uns exemples propers en el temps i l'espai- com en la combinació de poblacions decidides a assumir les

\footnotetext{
${ }^{98} \mathrm{ACA}$, "Papeles por incorporar", Cervera, sense numerar.

${ }^{99}$ Flocel SABATÉ, Municipi $i$ Regió a la Catalunya Baix-Medieval, Rafael Dalmau editor, Barcelona (en premsa).

${ }^{100} \mathrm{AHCO}$, pergamins A-410, A-491.

${ }^{101}$ Pere III proclamava "ut gentes simplices et pacifice volunt vivere sub pacis et defensione nostre" (ACA, Cancelleria, reg. 877, fol. 128 r).

${ }^{102}$ Els diferents indrets en tractes per acollir-se a les redempcions en la campanya de 1384 a 1386 s'adrecen al monarca, repetidament i de manera formulària, explicant que actuen "desijants que ells e la dita vila ab sos termes ab lo dit mer e mixt imperi e tota altra juredicció e ab tot ço que és estada venuda tornen a vostra dolça senyoria", raó formal per la que "vos offeren que de lur pròpria moneda pagaran lo preu de la reemçó lur e de les dites coses venudes" (ACA, Cancelleria, reg. 1560, fols. 42 v, 58 v, 66 v, 91 r, 109 r, entre molts altres).

103 "Al dit senyor" (rei) "és molt agradable que vosaltres vos reemats e tornets a la sua suau senyoria" (AHCO, pergamí A-222).

104 "Dulce et suave dominium" (ACA, Cancelleria, reg. 3381, fol. $1 \mathrm{r}$; transcrit a Bienvenido OLIVER, Historia del Derecho en Cataluña, Mallorca y Valencia. Código de las costumbres de Tortosa, I, Imprenta de Miguel Ginesta, Madrid, 1876, p. 407).
} 
redempcions jurisdiccionals a costat de les que requereixen moltes negociacions i, encara, d'unes altres que n'han de ser forçades.

La creença historiogràfica en una societat baix-medieval serenament regida per les seves regles ha fet ponderar l'anomenat pactisme, que respon a una realitat evident ${ }^{105}$, la qual, però, encerta l'adient explicació en la combinació de l'exposició de les regles del joc amb el coneixement del dinamisme de les forces que l'acoten i l'emmarquen, alhora que no pot ésser extrapolat com un fet diferencial exclusiu sinó que ha de ser inscrit dins de la dinàmica global del pensament polític medieval ${ }^{106}$.

El desig de definir la justificació del poder d'aquests monarques que es comportaven com a sobirans sense ser reis d'aquest país ha portat, en lògica deducció jurídica, a sobrevalorar la seva condició de comtes de Barcelona, especialment en constatar la identificació, practicada per la mateixa corona des del segle XIII, de la noció de comtat de Barcelona amb Catalunya. A partir d'aquí s'ha estés, fins a l'actualitat, el tractament, sobretot en obres de caire jurídic, del monarca com a comte o, de manera molt generalitzada, sota l'artificiosa titulació de comte-rei, tal vegada tradicional i lògica, fins i tot pretesament reflectidora d'una preeminència catalana en avantposar el títol comtal, però en res concordant amb la percepció del poder compartida pels coetanis del sobirà baix-medieval.

La ponderació del discurs regi esdevé el mateix parany que ha fet cenyir la historiografia recent, en pura concatenació jurídica, el concepte de municipi a concessions del monarca, negant-se, en plena coherència, a aplicar la denominació municipal a indrets aliens a la consideració reial ${ }^{107}$, malgrat que, en la realitat medieval, els diferents governs locals endegaren

\footnotetext{
${ }^{105}$ Tomàs de Montagut, Pactisme $i$ absolutisme a Catalunya: les grans institucions de govern (s. XV-XVI), "Anuario de Estudios Medievales", XIX (1989), pp. 669-679; Antonio MARONGIU, Lo "speculum principum" del valenzano Pere Belluga, "VIII Congreso de Historia de la Corona de Aragón (Valencia, 1967)", II, Valencia, 1970, pp. 62-63.

${ }^{106}$ Diferents autors ja n'han fet advertiment (Jesús LALINDE, El ordenamiento interno de la corona de Aragón en la época de Jaime I, "X Congreso de Historia de la Corona de Aragón [Zaragoza, 1979]", Zaragoza, 1980, p. 185; José Luís MARTín, Pactismo político y consolidación señorial en Cataluña tras la conquista de Sicilia, "Economía y sociedad en los reinos hispánicos de la Baja Edad Media", I, Barcelona, El Albir, 1983, p. 241) i altres han ponderat les fórmules pròpies de monarquies properes (T. F. RUIZ, Une royauté sans sacre: la monarchie castillane du bas moyen age, "Annales. Economies. Sociétés. Civilisations", 39-3 [1984], p. 438).

${ }^{107}$ Max TURULl-Jaume RiBalTA, "De voluntate universitatis". La formació i l'expressió de la voluntat del municipi (Tàrrega, 1214-1250), "Anuario de Estudios Medievales", 21 (1991), pp. 181-182.
} 
les pròpies actuacions corporatives des del dinamisme sòcio-econòmic ${ }^{108}$, equiparant-se mutuament rera la sola aprovació dels respectius senyors, sota la convicció que cada un d'ells gaudia d'una plena capacitat pràctica en els seus dominis.

La pretensió, inherent al discurs romanista justificatiu de la posició del príncep, d'interpretar el poder sobirà com a propi del rei des del seu origen ha propiciat, encara, no sols un cert maquillatge del passat sinó, alhora, un veritable retoc de la memòria alt-medieval. D'antuvi, per bé que el titular del comtat de Barcelona formalment es beneficiés dels successius acataments dels homòlegs des del segle XI fins al XIII i en aquesta darrera centúria rebés els drets superiors que poguessin pertànyer al rei francès, l'origen jurisdiccional procedia d'una diversitat comtal, i malgrat que s'acatés la superioritat barcelonina, no havien estat els avantpassats del comte de Barcelona els qui havien concedit la jurisdicció als antecessors de molts detentors baix-medievals.

A la vegada, la projecció de la visió unitària del passat sota la preeminència del mateix casal des de les primeres nits de la naixença nacional és insensiblement païda i continuada per la historiografia moderna, que hi veu una unitat en comptes d'una pluralitat comtal ${ }^{109}$, establint així el caliu idoni per a rebre, poc després, la invenció de l'existència d'un antic país unitari alt-medieval sota segell carolingi que es deia Marca Hispàni$\mathrm{ca}^{110} \mathrm{i}$ en el que sempre hi va gaudir una preeminència el comte de

\footnotetext{
${ }^{108}$ Josep Maria FONT RIUS, La administración financiera en los municipios catalanes medievales, "Historia de la Hacienda Española (épocas antigua y medieval)", Instituto de Estudios Fiscales, Madrid, 1982, pp. 202-208.

${ }^{109}$ Es reiterarà que, arran de la concessió de Carles el Gros a Guifré el Pilós, "des de a les hores li concedia lo Comptat de Barcelona y Principat de Cathalunya franch de subjecció al Rey de França", destacant així la dinastia sorgida de "Seniofré, Prefecto de Cataluña, de quien descienden los ilustres Condes de Barcelona", abocada a presidir un país que sota "Lothario no tenia encara lo títol de Cathalunya sinó de Espanya o Marcha de Espanya o fins de Aquitània" (respectivament: Onofre MANESCAL, Sermó vulgarment anomenat del Sereníssim Senyor don Jaume segon, justicier y pacífic rey de Aragón y compte de Barcelona, fill de Don Pedro lo Gran y de dona Constança sa muller, predicat a la Sancta Iglésia de la insigne ciutat de Barcelona a 4 de novembre del any 1597, Casa Sebastià Cormellas al Call, Barcelona, 1602, fol. 26 r; Gerónimo PUJADES, Crónica Universal del Principado de Cataluña, V, Imprenta de José Torner, Barcelona, 1829, p. 117; Andreu BosCH, Sumari, index o epítome dels admirables $i$ nobilíssims títols d'honor de Catalunya, Rosselló $i$ Cerdanya, Pere Lacavalleria, estamper, Perpinyà, 1628 [ed. facsímil Curial, Barcelona-Sueca, 1974], p. 89).

${ }^{110}$ Michel ZimmermanN, Le concept de Marca Hispanica et l'importance de la frontière dans la formation de la Catalogne, "La Marche Supérieure d'Al-Andalus et l'Occident Chrétien", Casa de Velázquez-Universidad de Zaragoza, Madrid, 1991, pp. 29-31.
} 
Barcelona ${ }^{111}$. Més enllà del correctiu historiogràfic ${ }^{112}$, les implicacions ideològiques a què es presta aquest recurs $^{113}$ d'alguna manera deuen ressonar en la perllongació, fins a l'actualitat, de l'expressió Marca Hispànica en obres de caire històric o, encara més, en la reiteració de popularitzades refaccions engrescades entorn de la locució. I també deuen ressonar, més o menys soterradament, quan, encara en els nostres dies, la història dels segles alt-medievals, tant en obres divulgatives com fins i tot en manuals universitaris, sovint s'explica resseguint principalment els comtes de Barcelona i gairebé ignorant la resta, malgrat ser tan sobirans uns com altres.

\section{RÉSUMÉ}

La grandeur de la monarchie est impulsée dans tout l'Occident européen du bas Moyen-Age par l'elargissement des idées fondées sur le droit romain. Cependant, en Catalogne elle subit une difficulté: Celle qui est propre à une coronne qui doit justifier son discours sur un passé pluriel et hétérogène et qui, parmi de graves difficultés socioéconomiques, est limitée par la puissance des baronnies et municipes s'affrontant mutuellement. A travers leurs différentes situations, les soubirans essaient de contrôler et d'accroître les revenus ainsi que la jurisdiction. Aussi prétendent-ils imposer un respect pour les régales et encore atteindre une reconnaissance globale. Toutefois leur manque de force les oblige à se débrouiller entre les pressions des baronnies et des municipes. Ces dernières invoquent une identification entre les propres intérêts et la cause royale à la fois qu'elles essaient d'amorcer une notion de jurisdiction royale juridiquement et législativement stable. Cette situation a contribué à la cohésion de la Catalogne et en plus elle a fourni un ensemble d'images qui a laissé sa trace dans l'historiographie postérieure.

\footnotetext{
I"Andrés Avelino PI Y ARIMÓN, Barcelona antigua y moderna o descripción e historia de esta ciudad desde su fundación hasta nuestros días, vol. I, Imprenta y librería politécnica de Tomás Gorchs, Barcelona, 1854, p. 43; Joseph CALMETTE, La question des Pyrénées et la Marche d'Espagne en moyen-âge, J. B. Janin, Paris, 1947, p. 18.

${ }^{112}$ Antonio de la TORRE, La reconquista en el Pirineo, "La reconquista española y la repoblación del país (Conferencias del curso celebrado en Jaca en 1947)", CSIC, Zaragoza, 1951, pp. 24-38; José Antonio Maravall, El concepto de España en la Edad Media, Instituto de Estudios Políticos, Madrid, 1954, p. 154; Ramon d'ABADAL, Nota sobre la locución "Marca Hispanica", "Boletín de la Real Academia de las Buenas Letras de Barcelona", XXVII (19571958), pp. 154-164.

${ }^{113}$ Michel ZIMMERMANN, Le role de la frontière dans la formation de la Catalogne (IXXIIème siècle), "Las sociedades de frontera en la España medieval", Universidad de Zaragoza, Zaragoza, 1993, p. 9.
} 


\begin{abstract}
SUMMARY
The increasing power of the monarchy in late-medieval Europe, was aided by the influence of the revivied Roman Law. The Catalonian monarchs faced the particular difficulty of having to justify their centralizing discourse despite a plural and heterogeneous part and the importance of mutually opposed noble and municipal powers that operated in a fragile social and economic context. The kings tried to control and to augment their revenues and jurisdiction and to impose royal rights and general respect. These objectives were weakened by the pressure of nobles and towns. The latter proclamed the identity of the their interest with the royal objectives and sought juridical and legislative stability under royal jurisdiction. This situation contributed to the cohesion of Catalonia, but has also had a lasting affect on Catalonian historiography.
\end{abstract}

